\title{
COVID - 19 infection: Angiotensin II has a major role in the mortality rate. Low dose of inhaled Nitric oxide may be the treatment.
}

The corresponding first author: Ahmed Samy Elsaid Elatiar

Postal code : 33634

Email : clever.scorpion@yahoo.com

Telephone number: 00201004276727

Highest academic degrees: Biologist, Academic researcher, Egypt.

Ph.D. in Biochemistry.

The $2^{\text {nd }}$ author: Iman Samy Elsaid Ali

Email: Arzt.imansamy@gmail.com

Phone number: 002010--------79

Academic degree: Cardiologist at National heart institute, Egypt

Masters of cardiovascular medicine

The word count for text only: 449 


\section{COVID - 19 infection: the perspectives on Angiotensin II role}

Ahmed Samy Elsaid, PH D in Biochemistry. Clever.scorpion@yahoo.com

Iman Samy Ali, cardiologist, arzt.imansamy@gmail.com

\section{Abstract}

Since who characterized COVID-19 as a pandemic, all scientists and clinicians studied the viral effects on the various organs and tissues of the infected patients. The virus irreversible binding to the ACE2 in the target cell in the lungs is the first step of the viral deleterious pathway to invade the target tissues. As the virus replicates and its number increase, the ACE2 in lung type II alveolar cells become inactive. ACE2 is also located in the arterial and venous endothelial cells and arterial smooth muscle cells in most organs. ACE2 is the enzyme catalyzing the conversion of angiotensin II to angiotensin (1-7). The accumulated angiotensin II has a paracrine effect in the pulmonary system in increasing the mean pulmonary pressure and vasoconstriction affect the lungs. One of the suggested treatments is the use of low dose inhaled nitric oxide, which has minimal systemic effects.

\section{Keywords: Angiotensin II, Potassium, angiotensin (1, 7), nitric oxide, covid 19}

\section{The manuscript}

The Novel Coronavirus 19, was first reported on in Wuhan, China in late December 2019. According to the $C D C$, the rate of American patients admitted to the ICU with a cardiovascular disease was $20 \%$ among US coronavirus patients. The patients admitted to the ICU with pulmonary issues (chronic lung disease, smokers and former smokers) was more than $39 \%$ As the CDC statistical analysis below. 


\section{COVID-19 cases based on pre-existing conditions}

\begin{tabular}{|c|c|c|c|c|}
\hline $\begin{array}{l}\text { PRE-EXISTING } \\
\text { CONDITION }\end{array}$ & $\begin{array}{l}\text { CASES PER CONDITION } \\
\text { Counts are among the } 7,162 \\
\text { cases with completed information } \\
\text { on pre-existing conditions. }\end{array}$ & \multicolumn{3}{|c|}{$\begin{array}{l}\text { PERCENT OF THOSE } \\
\text { CASES THAT ARE: }\end{array}$} \\
\hline Chronic liver disease & 41 & $59 \%$ & $22 \%$ & $17 \%$ \\
\hline Current smoker & 96 || & $64 \%$ & $23 \%$ & $5 \%$ \\
\hline Former smoker & 165 & $48 \%$ & $27 \%$ & $20 \%$ \\
\hline Chronic renal disease & 213 || & $24 \%$ & $45 \%$ & $26 \%$ \\
\hline Immunocompromised & $264 \|$ & $53 \%$ & $24 \%$ & $16 \%$ \\
\hline Cardiovascular disease & $647 \square 1$ & $37 \%$ & $37 \%$ & $20 \%$ \\
\hline Chronic lung disease & $656 \square 1$ & $55 \%$ & $23 \%$ & $14 \%$ \\
\hline Diabetes mellitus & 784 & $42 \%$ & $32 \%$ & $19 \%$ \\
\hline Other chronic disease & 1,182 & $49 \%$ & $30 \%$ & $14 \%$ \\
\hline One or more & 2,692 & $52 \%$ & $27 \%$ & $13 \%$ \\
\hline None of the above & 4,470 & $\mathbf{8 4 \%}$ & $7 \%$ & $2 \%$ \\
\hline \multicolumn{5}{|l|}{ Status unknown } \\
\hline \multicolumn{5}{|c|}{$\begin{array}{l}\text { Source: CDC Data as of March 28, } 2020 \text { at } 12 \text { p.m. EST. (Business Insider/Skye Gould, data from } \quad \text { IN IN IDER } \\
\text { CDC) }\end{array}$} \\
\hline
\end{tabular}

\section{Angiotensin-converting enzyme 2}

The virus infects the target cell through the binding of the viral spike (s) glycoprotein with the ACE2. A drop in the ACE2 level, increase in the Ang II (Angiotensin II) level and decrease in the Angiotensin $(1,7)$ level was reported as the protein is degraded in the cell(1).

\section{Angiotensin II}

Angiotensin II is reported to increase the sympathetic activity (2) and decrease the potassium level in blood $(3,4)$, which may have a rule in the increase of mortality rate. Therefore, the treatment should contain potassium as a component of the therapeutic course.

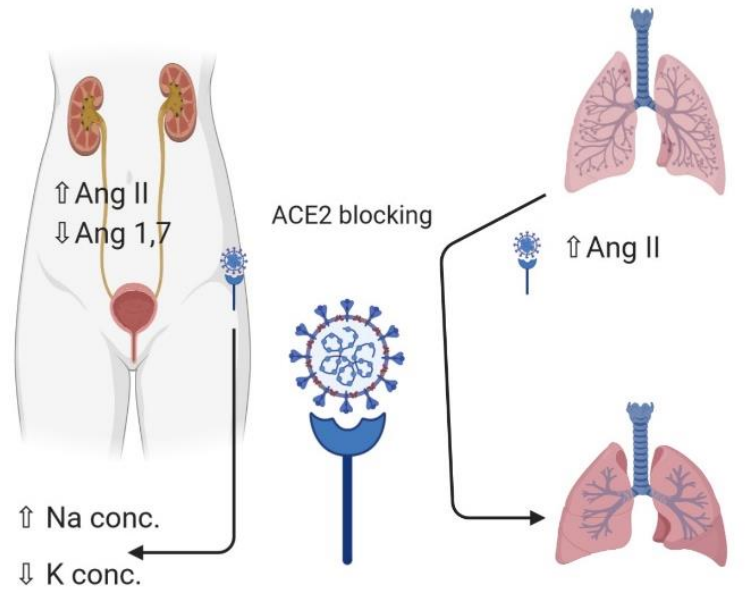


Fig 1 : The covid 19 effect on Ang 2 and lungs.

\section{The pulmonary renin-angiotensin system}

The paracrine expression of renin-angiotensin-system (RAS) components play an increasingly recognized as an important role in the lung injury. Activation of a local RAS within the pulmonary circulation and lung parenchyma could influence the pathogenesis of lung injury via a number of mechanisms including an increase in vascular permeability, vascular tone and fibroblast activity, and by reducing alveolar epithelial cell survival $(5,6)$. As the virus irreversibly bind to the pulmonary ACE2 cells, the angiotensin II could be increased $(7,8)$ and the mean pulmonary arterial pressure and total pulmonary vascular resistance (9). Nicin et al., (2020) reported that an increase in the vasoconstriction in the covid - 19 patients was observed(10).

In addition, treatment with angiotensin $(1,7)$ may be studied as a possible treatment of covid 19 infection. Angiotensin-(1-7) downregulates the angiotensin II type 1 receptor in vascular smooth muscle cells (11). Angiotensin $(1,7)$ is a truncated form of Ang II, lacking phenylalanine in the eighth position. Its functional role in counterbalancing Ang II actions (12).

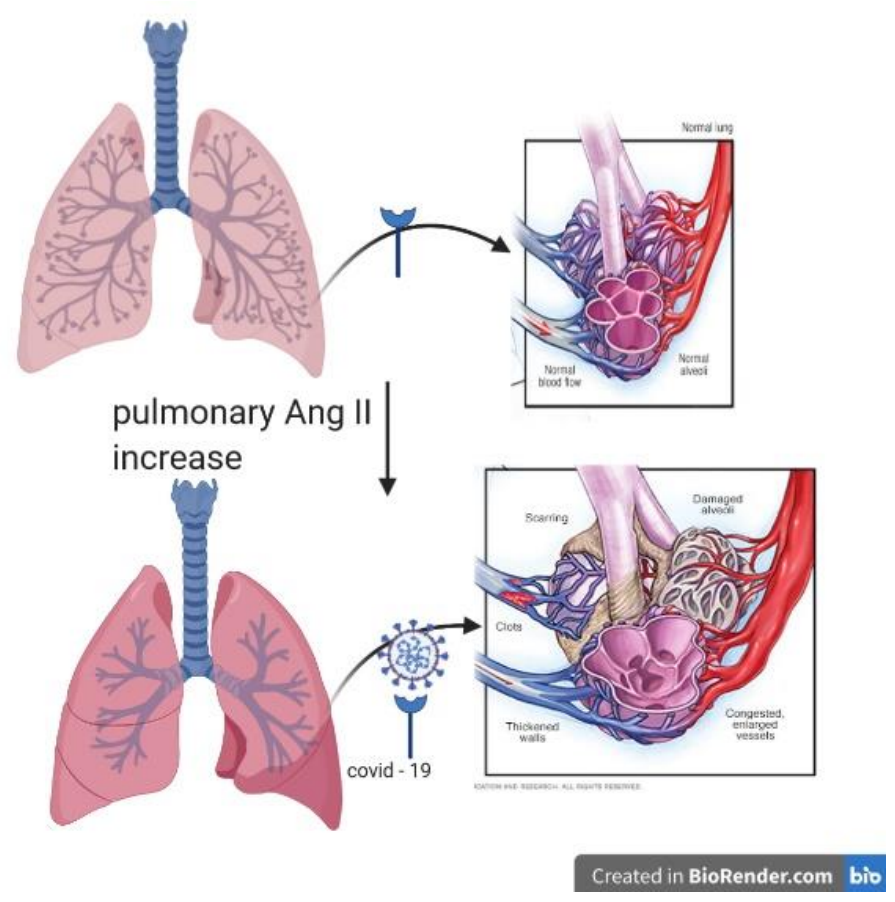

Figure 2 : The paracrine effect on Ang II in lungs

The use of low-level inhaled Nitric oxide could be tested, as a vasodilator, it has a good effect on the lung (13). Inhaled nitric oxide has been reported to improve oxygenation in acute lung injury as it has minimal systemic effects (14). Nitric oxide simultaneously increases $\mathrm{PaO} 2$. In addition to macrophages, a large number of other immune-system 
cells produce and respond to NO. It also regulates the functional activity, growth and death of many immune and inflammatory cell types including macrophages, $T$ lymphocytes, antigen-presenting cells, mast cells, neutrophils and natural killer cells (15).

\section{Summery}

Treatment with low dose inhaled Nitric oxide can be done first to preserve the patient's condition and as a quick solution at first, and then inject him with angiotensin $(1,7)$ for varying periods to maintain the rate of angiotensin II / angiotensin $(1,7)$ which will provide two antagonists to the angiotensin II to decrease its effect on the infected tissue. In addition, this will increase the blood flow to the infected tissue, which will decrease the virus effect and will enhance the immune response. The nitric oxide usage will also increase the immune response, which will lower the infection period. Angiotensin $(1,7)$ has anti - angiotensin II effect and should be used as a potential treatment.

\section{References}

1- Ankit B, Ashish V, MBBS1 COVID-19 and Angiotensin-Converting Enzyme Inhibitors and Angiotensin Receptor Blockers. JAMA Published online March 24, 2020

2- Reid IA. Interactions between ANG II, sympathetic nervous system, and baroreceptor reflexes in regulation of blood pressure. Am J Physiol. 1992 Jun;262(6 Pt 1):E763-78.

3- Veiras LC, Han J, Ralph DL, McDonough AA. Potassium Supplementation Prevents Sodium Chloride Cotransporter Stimulation During Angiotensin II Hypertension. Hypertension. 2016 Oct; 68(4):904-12.

4- Singhi S, Gulati S. Frequency and Significance of Potassium Disturbances in Sick Children. INDIAN PEDIATRICS. 1994 APRIL; 31: 460 -3.

5- Marshall RP. The pulmonary renin-angiotensin system. Curr Pharm Des. 2003;9(9):715-22.

6- Frossard M, Joukhadar C, Steffen G, Schmid R, Eichler HG, Müller M. Paracrine effects of angiotensin-converting-enzyme- and angiotensin-II-receptor-inhibition on transcapillary glucose transport in humans. Life Sci. 2000;66(10):PL147-54.

7- Ryan J W, Stewart J M, Leary W P, and Ledingham J G. Metabolism of angiotensin I in the pulmonary circulation. Biochem J. 1970 Nov; 120(1): 221-223.

8- P Biron, L Campeau, P David. Fate of angiotensin I and II in the human pulmonary circulation. The American Journal of Cardiology. 196;9 24, 4: 544-547

9- Clark MA, Diz DI, Tallant EA. Angiotensin-(1-7) downregulates the angiotensin II type 1 receptor in vascular smooth muscle cells. Hypertension. 2001 Apr;37(4):1141-6. 
10- Lipworth BJ, Dagg KD. Vasoconstrictor effects of angiotensin II on the pulmonary vascular bed. Chest. 1994 May;105(5):1360-4.

11- Luka Nicin, Wesley Tyler Abplanalp, Hannah Mellentin, Badder Kattih, Lukas Tombor, David John, Jan D Schmitto, Jörg Heineke, Fabian Emrich, Mani Arsalan, Tomas Holubec, Thomas Walther, Andreas M Zeiher, Stefanie Dimmeler Cell type-specific expression of the putative SARS-CoV-2 receptor ACE2 in human hearts. European Heart Journal, ehaa311, https://doi.org/ 10.1093/eurheartj/ ehaa311.Published:15 April 2020

12- Jasmina Varagic, Sarfaraz Ahmad, Sayaka Nagata and Carlos M. Ferrario. ACE2: Angiotensin II/Angiotensin-(1-7) Balance in Cardiac and Renal Injury. Curr Hypertens Rep. 2014; 16(3): 420.

13- Gómez FP, Amado VM, Roca J, Torres A, Nicolas JM, Rodriguez-Roisin R, Barberà JA. Effect of nitric oxide inhalation on gas exchange in acute severe pneumonia. Respir Physiol Neurobiol. 2013 Jun 15;187(2):157-63.

14- Robert W. Taylor, Janice L. Zimmerman, R. Phillip Dellinger, et al Low-Dose Inhaled Nitric Oxide in Patients With Acute Lung Injury. JAMA. 2004;291(13):1603-1609.

15- Parul Tripathi, Prashant Tripathi, Luv Kashyap, Vinod Singh. The role of nitric oxide in inflammatory reactions FEMS Immunology \& Medical Microbiology. 2007; 51; 3: 443-452. 